\title{
A forced migration from Myanmar to Bangladesh and beyond: humanitarian response to Rohingya refugee crisis
}

\author{
Malang Faye
}

\begin{abstract}
It is widely agreed that the Rohingya Muslims of Myanmar are currently named as the most persecuted minority in the world. The racial prosecution is triggered by the decades of longstanding insurgency between the Government of Myanmar and the Rohingya Muslims over the issues of religious and ethnic discrepancy. This article presents the measures taken by the international community to stop these mass killings. The article offers critical insights into strategies used by Myanmar's government to suppress the Rohingyas. This study highlights the rights violation and humanitarian struggle faced by the Rohingya people and the humanitarian response to the crises by the international community.
\end{abstract}

Keywords: Human rights, Refugee, Prosecution, Rohingya, Intervention

\section{Introduction}

Located in Southeast Asia, Myanmar is a least-developed country. The country was proclaimed as Burma by the 1947 constitution. The name was later changed to Myanmar by the then military junta. The 2008 constitution's official name of the country is "The Republic of The Union of Myanmar" (Mohajan 2018). The population of Myanmar is estimated at 54.5 million people according to the UN 2020 midyear data. Myanmar's population is equivalent to $0.7 \%$ of the total world population. The country's total land area is $653,290 \mathrm{~km}^{2}$ (252,237 sq. mi) (Worldometer 2020). Myanmar is among the most diverse countries in the world. Throughout history, settlers from various ethnic backgrounds have moved around the great horseshoe of mountains which encircled the Irrawaddy river plain. The Myanmar 1974 constitution (now being revised) established seven ethnic minority states (the Chin, Kachin, Karen, Kayah (formerly Karenni), Mon, Rakhine (or Arakan), and Shan) and seven divisions, which are largely

Correspondence: fayemalang@gmail.com

School of Arts and Science, The University of The Gambia, Serrekunda, The Gambia inhabited by the majority Burman population (Smith 2002). These minority groups are estimated to make up at least one-third of Myanmar's population and inhabit half of the land cover (Smith and Allsebrook 1994).

Myanmar was annexed by the British during three wars which were carried out between 1824 and 1886 . The British occupation of Myanmar lasted for over 60 years. Before the British occupation of Myanmar, interethnic harmony was in a very good shape, until the unwelcome meddling of British rule in the nineteenth century. During this period, ethnic tensions stuck between different communities, dangerously inflamed by the divide and rule tactics of the colonial government. This division set the various ethnic groups on extremely separate ways towards economic and political development, resulting in communal violence in many instances in their history. Nevertheless, Myanmar's historians have pointed fingers to the British for favouring ethnic minorities during colonial rule and had equally damaging consequences for ethnic minority aspirations, as ethnic minority lands were divided into separate political districts, and none was administered based on nationality (Smith and Allsebrook 1994). 
At the west coast of Myanmar is the Rakhine state, one of the poorest regions of the country with an area size of 14,200 sq. mi. According to Mohajan (2018), there are 3.8 million people in Rahkine, where an estimate of $59.7 \%$ are Buddhist, $35.6 \%$ are Muslim (Rohingya) and the rest from the remaining religious groups (Mohajan 2018). The Rohingyas originated from different ethnic groups which include Arabs, Moghuls and Bengalis. The divide and rule in Arakan by the British resulted in many of the Arakanese Buddhist developing hatred against the Rohingyas and treated them as foreigners. This hatred against the Rohingya Muslim can be viewed as a result of British imperialism. However, the same policy was later adopted by the military junta of Burma. Notwithstanding, it is important to note that the Rohingyas did not suddenly appear in Arakan, but evidence has shown that they were descendants of Arabs who arrived 1200 years back (Tha 2007).

Since after independence, the Rohingya Muslims suffer numerous human rights abuses such as mass killings, rape, and torture, and this has continued till today. These have created a chronic refugee crisis in neighbouring Bangladesh. As of late, thousands of Rohingyas remain displaced depending on humanitarian aid for survival, while some also undergo brutal repression by the Myanmar border guard (Abdelkader 2013).

The 1982 Citizenship Act codified the legal omission of the Rohingya, making human rights and humanitarian condition of the Rohingya worse. The Act officially identifies 135 national races that qualify for citizenship. The Rohingya exclusion denied the full benefits of citizenship in what is described as "nonindigenous ancestry". Under this Act, the Rohingya can only possess Foreign Registration Cards, which are rejected by many schools and employees. The Rohingyas are denied their right to own property, marry and freedom of movement. These rights are guaranteed under international law (Abdelkader 2013).

Moreover, Rohingya's crisis is not only religiously founded, it comprises both economic- and politicalrelated issues. The Rohingyas were viewed as economically developed by the Buddhists of Myanmar who thought that their culture is under siege than that of the Rohingya. This coupled with the deeply entrenched Islamaphobia in Rakhine and Myanmar being surrounded by Islamic countries, like Indonesia, Malaysia and Bangladesh. The Buddhists also fear that the Rohingya might turn against Myanmar if they happen to enter a war with any Islamic country. For this reason, the Rohingyas are culturally discriminated, exploited and side-lined from politics (Mohajan 2018).

The sectarian battle focuses on Muslim regions that are in the northern part of Rakhine state: Maungdaw, Rathedaung and Bathidaung Township. The past decades saw that the Rohingya ethnic group suffers from massive violence in Rakhine resulting in ethnic cleansing and genocide (Mohajan 2018). The human rights violation in Myanmar suffered by the Rohingya agonises several forms of human rights violations, ranging from land confiscation, destruction of mosques, torture, forced labour and extrajudicial executions (Mohajan 2018).

\section{Understanding forced migration in Myanmar}

The term forced migration has been debated internationally because of the prevalent recognition that a continuum of agency exists rather than a voluntary/ forced dichotomy. The term forced migration has been used to describe the movements of refugees, displaced person and, in some instances, victims of trafficking (IOM 2019). According to the IOM, forced migration can be defined as "A migratory movement which, although the drivers can be diverse, involves force, compulsion, or coercion" (IOM 2019, P77).

South et al. argued that there are three kinds of forced migration operated in Myanmar. Firstly, armed clashes between Rakhine Buddhists and Rohingya Muslims leading to the successive displacement. Secondly, the military occupation of this border state leading to displacement. Thirdly, is the vulnerability of livelihoods which caused internal as well as external migration (Mehebub Sahana 2019; Jolliffe 2015).

\section{Forced migration from Myanmar to Bangladesh and beyond}

The systematic violation of human rights of the Rohingya by Myanmar's military junta has forced thousands of Rohingya to flee the country. Subsequently, compelling thousands to live as a refugee, mainly in Bangladesh, while others flee to countries like Malaysia, Singapore and the Middle East. For many, taking refuge in Bangladesh was something that has never been expected. However, seeking refuge to Bangladesh did remove them from their suffering (Parnini 2013).

Some of the migrants have been denied access to refugee camps, and they often survive in extreme poverty in villages or slums near Cox's Bazar and Teknaf. They are invisible and at times labelled as economic migrants by the authorities in Bangladesh (Ullah 2011; Holloway and Fan 2018).

Myanmar and Bangladesh share a $168 \mathrm{~km}$ border, but security and political issues occasionally disturb the bilateral relationship between the two countries. For example, the Rohingya refugees who cross the border temporarily and continue to live in camps in bordering Cox's Bazaar district of Bangladesh. The government of Myanmar has shown excessive hesitation to accept these Rohingyas as citizens, and in short, they consider them as foreigners (Parnini 2013; Ullah 2011). Moreover, Rohingyas in Bangladesh are unhappy to be sent back to 
Myanmar as they believe that the authorities would persecute them. The fear of being persecuted has been raised by the refugees, and the foreign minister of Bangladesh has raised this issue in her visit to Myanmar. Although Bangladesh's authorities want to see the Rohingyas repatriated as they are wary that their national resources will be drained, yet pushing them back will be inhumane in the face of the Rohingya crisis. The Bangladesh government is accused of engaging in forcible repatriation, even though they refer to it as involuntary repatriation. Even the UNHCR has pointed out that this was directed by the Bangladesh government in some instances (Parnini 2013).

The 1977 Nagamin census was conducted in order to screen out foreigners and register citizens, which resulted in the oppression of Rohingyas, and as a result, 200,000 fled from Myanmar for Bangladesh in 1978. A mass exodus of more than 300,000 Rohingyas fled persecution in the Arakan State within a period of 4 months, from December 1991 to March 1992 (Ullah 2011).

Despite several negotiations between the government of Myanmar and the Government of Bangladesh for over 12 years, 226,576 were repatriated to Myanmar. Nonetheless, persecution has not stopped as Rohingyas continue to suffer in the hands of the military. In 2009, in just 3 days, 1000 Rohingya Muslims entered Bangladesh claiming the increasing persecution they face from the military. They were forced out of their homes and threatened. For example, in Rakhine, Rohingyas were forcefully evicted, and the military cleared their spaces and built army barracks (Ullah 2011).

However, Bangladesh has failed to provide enough protection as UNHCR was unable to give adequate support. For example, the average household size in the camps is between six to seven persons regardless of the family size. Although the UNHCR standard guideline of 15-20 L of water per person a day was still an issue due to the large number of people. The operating time of the tap water was $2 \mathrm{~h}$ daily, while in many cases it opens for less than $2 \mathrm{~h}$ and that was not enough for all those in the kutupalong camp.

Additionally, informal primary education was also established in 2001. The school started to operate with 5532 children. Moreover, the Rohingyas were not allowed to search for employment beyond the camp; however, some engage in small petty business outside the camp along the roadside mostly throughout the camp. Notwithstanding, many young female Rohingyas resorted in the sex trade business, though the restriction on their movement has some negative impact on their quality of life. These have resulted in a high rate of pregnancy and birth rate outnumbering the number of deaths and repatriation if combined in recent years (Ullah 2011).

\section{UNHCR intervention}

United Nations High Commissioner for Refugees (UNHCR) became a prime international actor in the Rohingya refugee catastrophe. The UNHCR has played an integral role in the Rohingya refugee crisis during 1990s branding Aung San Suu Kyi as its ambassador. Starting its campaign in Myanmar, UNHCR enormously exposed the status of Aung San Suu Kyi as its "messenger of peace" in Myanmar by flourishing the idea of harmonious neighbourhood between Rohingya community and other Myanmar's major ethnic groups. From the 1990s onwards, UNHCR established a national office in the Capital of Myanmar, Yangon, following the support of Aung San Suu Kyi. Moreover, leading to the turbulent domestic political contest between Junta and Aung San Suu Kyi-led National League of Democracy (NDL) party, UNHCR had to bear resistance from the Military junta administration. This prompted many of UNHCR officials to be forcibly returned back due to the fact that they have been denied visa extension.

In 1993, during a meeting held to discuss the possible solutions for the 250,000 Rohingya refugees who fled from Myanmar to Bangladesh, a senior UNHCR staff member was quoted saying "these are primitive people (referring to the Rohingyas). At the end, they will go where they are told to go". This statement reflects the exemplary of the organisation engagement with the Rohingyas for years and the lack of willingness to uphold the UNHCR protection principles. Moreover, Jeff Crisp also highlighted that from the unpublished material by UNHCR, in 1970s and 1980s, many refugees were sent back to Myanmar in a way that was untimely, involuntary and unsafe (Crisp 2018).

Notwithstanding, according to Crisp, the UNHCR evaluation service which was later prepared was questionable whether the 1978 repatriation was voluntary or not. The paper further explains that early repatriation was the main objective of the Bangladesh government from the beginning of the crisis. To make this possible, the Bangladesh government uses various tactics to stop refugees, ranging from several attacks on the Rohingya refugees. However, the UNHCR noted that the Rohingya refugees were not willing to repatriate. Nonetheless, Bangladesh's government was ready to take all measures to ensure these migrants repatriate even to use force when necessary. The UNHCR mentioned that the reason for the high number of returning refugees is because of serious happenings in the camp leading to the high number of deaths by the Rohingyas (Crisp 2018).

Another tactic used by Bangladesh's government to force repatriation was to withhold food and other basic essential assistance from the refugees. An experienced UN official labelled the Rohingya camps as "death trapsthe worst I have ever seen". This led to malnutrition 
mounting, and by July 1978, the mortality rate in the camps was four times higher than the rest of Bangladesh. The UNHCR staff member noted that the Bangladesh government policy has become one that starves refugees prompting them to leave. The lack of basic needs resulted to widespread malnutrition and death rates (Crisp 2018). At the end of the repatriation process in January 1980, during press conference, the UNHCR acknowledged that 10,000 refugees had died in the camps, referring to epidemics as the principal cause. However, privately, staff in the field acknowledged government failure to deliver food supplies which was readily available as the cause of the high mortality rate. However, this is not an excuse for organisations like the UNHCR whose responsibility includes providing welfare to comply with a policy resulting to more than $9000 \mathrm{su}-$ perfluous deaths (Crisp 2018).

Contrary to the UNHCR protection responsibilities, refugees were not consulted about the repatriation process and what waited on them. The UNHCR did very little effort to halt the abuses faced by the Rohingyas in the camps, although two field staffs have tried to raise the issue, they were remove from the operation. In an effort to deflect criticism, the UNHCR has stated that it has little involvement in the repatriation and argues that they did not have the mandate responsible of determining the voluntary character of the decision taken by refugees to return.

During this time, any form of advocacy on human rights issues in Myanmar was perceived as a threat to the ruling power, predominantly those that talked about the Rohingya crisis. The failure of this intervention by the UNHCR threatened the lives of their officials working in the country.

Following the intricacies of domestic insurgency, the UNHCR established a number of refugee camps in the nearest state borders next to Myanmar region mainly in Bangladesh the closest neighbouring state. Consequently, this led to the first attempt by the UNHCR to build a camp outside Myanmar for early rehabilitation and temporary resettlement, by providing temporary housing and livelihood aids for conflict-affected refugees. This was the first strategy employed by the UNHCR to intervene in the crisis. This had also scaled up fundraising campaign to receive basic logistics supplies such as food and medical facilities. Additionally, the UNHCR also made available doctors to mobile around the camps for emergency purposes. The UNHCR further adopted several policies for a more strategic service delivery based on international enforcement of the non-refoulement principle in Geneva convention 1951. The convention claimed those with refugees be resettled in camps whether formally registered or not or taking voluntary consent from the refugee in person.
It is important to note that one of the characteristics of Southeast Asian states is that majority of them are not signatories to international treaties concerning migrants and refugee that might provide protection for the rights of Rohingya migrants. Additionally, ASEAN member states are legally sealed by a Treaty of Amity and Cooperation within the ASEAN constitutional framework which strictly preserves the prevention to breach domestic issues of the other member-state (ASEAN 1976).

This absurdity exposes another standstill situation that ruined the mitigation of Rohingya situation. As a result of this, neighbouring states can deliver but only limited to raising and sending aids. International customary norms can be activated as the basis to protect the rights to life, and therefore, the Non-Refoulement principle may enter into force in the absence of legal framework. The basis of non-refoulement is supported out by UNHCR in every humanitarian mission to guard principal human rights (Jacqueline Joyce F, 2010). Regarding human rights, it is clear that certain rights are inviolable right and cannot be taken from the human being. Therefore, non-signatory states or signatory state is expected to carry out non-violent approach in humanitarianism in respect of human rights. In 2007, the UNHCR issued an Advisory Opinion emphasising the importance of state commitment to the principle of Non-Refoulement.

It is also important to stress that immigration officers of the third state are obliged to guarantee the safety of refugees so as not to experience the same human rights abuse in the destination country. Based on this principle, the UNHCR provides two options. First is to offer voluntary repatriation to Rakhine state or to set up a new relocation site to enable local community integration with the host native inhabitants (voluntary consent). This is to prevent migrants being force which can result to another causality.

\section{ASEAN intervention}

The Association of Southeast Asian Nations (ASEAN) has been cognisant of the Rohingya's dilemma since the 1990s. This problem was recognised by countries like Malaysia and Thailand. Due to the high influx of migrants into Bangladesh and the trafficking of Muslims into both Malaysia and Thailand, the governments of Thailand and Malaysia had signalled that this problem cannot be taken as domestic issue as it might create a potential area of instability in the region or human suffering. However, when Myanmar joined the ASEAN, the issue of Rohingyas was ignored by ASEAN to address some of the difficulties faced by Rohingya's or problem caused by other state which might be a threat to regional integrity (Rahman 2015; Parnini 2013).

In Myanmar, the ruling regime obstinately declined to recognise the Rohingyas as citizens and not part of the 
indigenous people, adding more uncertainty on how to contain the refugee crisis. Thailand for years has been a frontline in the humanitarian crisis hosting over 120,000 refugees. However, Thailand was also facing the problem of insurgency and believed that the arrival of more stateless Rohingya could boil the insurgency.

Despite the poor track record of Malaysia on ratification of international human rights treaties and harsh immigration laws and policies, they hosted between 20,000 and 25,000 Rohingyas.

Notwithstanding, it is important to note that both Malaysia and Thailand are not signatories to the 1951 United Nations Convention relating to the status of refugees or 1967 protocol on the rights crisis of the Rohingya (minorities) (Parnini 2013).

Moreover, ASEAN has been criticised for its handling of the Rohingya crisis by the international community for not sharing responsibility for solving the Rohingya problem. In 2010, at the ASEAN summit, Myanmar foreign minister said refugees will be allowed to go back to Myanmar only if they recognise themselves as Bengalis born in Myanmar not Rohingya; this comment was seen as problematic by many. Additionally, many have viewed this as an excuse by the Myanmar regime to avoid embarrassment while ignoring the root problem. ASEAN leaders have also called for national reconciliation and dialogue with Aung San Suu Kyi but did not put emphasis on the Rohingya crisis (Parnini 2013).

\section{International community intervention}

The Rohingya crisis has not been taken seriously by the international community for very long, resulting to a series of crises and mass exodus of Rohingya from Myanmar to neighbouring countries. The massive scale of oppression faced by the Rohingyas not only threatened their life but left them vulnerable in the hands of traffickers and terrorists. Nonetheless, Myanmar has been criticised by western powers for its poor record of human rights. In May 1978, Reuters reported that UNHCR's Paul Hartling was quoted saying he has set apart US\$ 500,000 for the 200,000 Rohingya refugees who fled to Bangladesh. On the other hand, the Organisation of Islamic Cooperation (OIC) issued a statement in Jeddah in May 1978 that the Rohingya Muslims are suffering from massive atrocities which has been mentioned by different various reliable sources. This was followed by a negotiation with the support of OIC and UN between Myanmar and Bangladesh resulting to the returning of the Rohingya to Arakan in 1978. Nevertheless, the agreement did not mention anything related to the status of the Rohingyas, properties or security after their return. Despite the return agreement in 1978, the military junta conducted another massive terror attack on the Rohingya triggering massive exodus of Rohingya in 1992 once again (Parnini 2013).

This has resulted in 250,000 Rohingya fleeing to Bangladesh who were officially recorded for relief. Yet, many could not register for shelters on their own in Chittagong. Consequently, prolonged negotiation was held by UNHCR, Bangladesh and Myanmar to reach an agreement on repatriation. This paved the way for repatriation, and by July 1995, a total of 192,467 out of the 250,877 registered refugees who crossed into Bangladesh between 1991 and June 1992 were repatriated under the supervision of UNHCR. Notwithstanding, repatriation was to stop as the Myanmar Army was reluctant to abide by the agreement as the SLORC regime had decided to take an average of 20,000 Rohingya refugees every month from all the camps in Bangladesh (Parnini 2013).

In December 1994, the $\mathrm{Al}$ report on Myanmar highlighted that no significant development on human rights violations had been made by Myanmar regime on minorities (Rohingyas). Despite the massive violation, the UN security council was silent in spite of the agreement that the security council take action under the Responsibility to Protect (R2P) if governments fail to protect their population. In 2007, a draft security council resolution on the ground of violation in Myanmar was rejected by China and Russia stating the crisis is not a threat to international peace. Countries like the USA has continued to put pressure on Myanmar regime with sanctions and clearly stated in 2010 that they have no plans to lift sanction on Myanmar if violations continue to happen. However, a democratic Myanmar will open more doors through viable diplomacy and will be a win-win situation for Myanmar and the international community.

In 2019, the pressure intensifies on Myanmar's government to put to an end the killing of Rohingyas and other ill-treatments. During the 2019 OIC summit in Makkah, The Gambia was tasked by the OIC to use all international legal instruments to hold accountable the perpetrator of crimes against the Rohingyas in Myanmar (The Republic of The Gambia Office of The President n.d.). The Gambia then filed a lawsuit against Myanmar accusing it of perpetrating a genocide on ethnic Rohingya at the International Court of Justice (ICJ). This is seen as unusual coming from a very tiny West African country, The Gambia (Besheer 2019).

The Gambia, with the full backing of all the 57 member countries of the Organization of Islamic Countries, aims to get Myanmar to account for its action against its people (Rohingya). In a press conference in the Hague, Justice Minister Abubacarr Tambadou said: 
It is a shame for our generation that we do nothing while genocide is unfolding right under our own eyes. (Berg 2019).

Further elaborating on the initiative, Mr Tambadou said "visiting Cox's Bazar in Bangladesh had reminded him of his work as a prosecutor for the tribunal set up to try those responsible for the 1994 genocide in Rwanda". "I thought this was not right and the world cannot just stand by and watch this happen again," he said, adding the OIC had asked. The Gambia to look into how to bring Myanmar to justice over the matter (Berg 2019).

In a 46-page filing to the ICJ, Gambia says Myanmar's actions were "genocidal in character" and included killing, causing serious bodily and mental harm and imposing measures to prevent births. Gambia asked the ICJ to grant so-called provisional measures to make sure Myanmar immediately stops the alleged atrocities (Berg 2019).

Since August 2017, more than 700,000 Rohingya Muslims fled neighbouring Bangladesh due to the crackdown by Myanmar's military, which UN investigators say was carried out with "genocidal intent". Buddhist majority of Myanmar denies accusations of genocide (Besheer 2019). The government of Myanmar has strongly disputed accusations of genocide and has established its Commission of Inquiry.

"This is clearly a politically motivated international pressure tactic against Myanmar on the issue of Rakhine state”, Myanmar's UN Ambassador Hau Do Suan told VOA in an email. "Gambia has nothing to do with Myanmar's problem. The OIC and Gambia should try to put their backyard in order first, before trying to interfere in the affairs of a faraway country which is trying its best to find a sustainable and peaceful means to solve its own problem." (Besheer 2019). He said Myanmar is implementing "in good faith" recommendations issued in 2017 from an international advisory commission on addressing root causes of the crisis and would not "surrender to this kind of unfair, intimidating, political and religious-based pressure" (Besheer 2019). The ICJ's provisional measure orders are legally binding on the parties. This is because all members of the UN, including Myanmar, are bound by the ICJ Statute. Whether Myanmar will comply with the court's orders and decisions, The Gambia has asked the court to require Myanmar to deliver the court with a report on actions taken to implement provisional measures order with 4 months from its issuance. Failing to comply, other UN bodies could take steps to increase the power of the IC)'s order and, by extension, increase the political cost. Moreover, article 94 of the UN Charter, all member countries must abide by ICJ decisions in cases to which they are a party, and in the event of non-compliance, the UN Security Council may "decide upon measures to be taken to give effect to the judgement (United Nation 1945). Additionally, article 41 (2) of the ICJ status, provisional measures are automatically transmitted to the UN Security Council for review. For example, the Security Council could pass a resolution directing Myanmar to lift restrictions on Rohingya's freedom of movement, reverse discriminatory laws, eliminate unwarranted restrictions on humanitarian access to Rakhine State and ban practices that limit Rohingya access to education, health care and livelihoods. Thus far, the Security Council has been deadlocked on Myanmar, in part because of China's support for Myanmar's leadership and its veto power (Human Rights Watch 2019).

\section{Conclusion}

The Rohingya can be termed as the most persecuted minorities in the world for a very long period. Despite the humanitarian assistance, not much support has been received from aid organisations. They have been denied their human rights ranging from the state to social authorities. Security remains a key priority in the world; however, Rohingya face the dilemma of security in this global era. With the little effort from the international community, Rohingya refugees are seen as a burden for Bangladesh, though, it tries to help at the best way possible for the sake of the refugees. Notwithstanding, Myanmar should also come forward to solve the problem replying to the call of the global community. Moreover, non-government organisations should be involved to play a more active role in the crisis in terms of humanitarian response in the Rohingya crisis. Despite the worsening condition faced by the Rohingya, more resources will somehow rescue the situation for the thousands of refugees living in fragile conditions. Finally, from this study, one can also suggest that local host communities of the Rohingya refugees should be supported and be made aware of the support provided and ease the pressure. Moreover, stakeholders both national and international should put measures to support community engagement between refugees' communities. Additionally, local actors should be supported and strengthened to ensure a more effective response.

\section{Abbreviations}

ASEAN: Association of Southeast Asian Nations; NDL: National League of Democracy; OIC: Organisation of Islamic Countries; R2P: Responsibility to Protect; UNHCR: The United Nations High Commissioner for Refugees; UN: United Nations; USA: United States of America

\section{Acknowledgements}

This article is dedicated to all humanitarian workers and human rights activist in Myanmar. I would take this opportunity to thank the anonymous proof-reader for their support and guide to make this article a success. I would like to thank my friends and colleagues for taking their time to go through my paper and for inspiring me for excellence. 


\section{Author's contributions}

I declare that I have read and approved this as the final manuscript.

\section{Funding}

I declare that this article has not been funded by any organisation or individual.

\section{Availability of data and materials}

Not applicable.

\section{Declaration}

\section{Competing interests}

The author declares that they have no competing interests.

Received: 18 May 2020 Accepted: 15 April 2021

Published online: 11 June 2021

\section{References}

Abdelkader E (2013) The Rohingya Muslims in Myanmar: past, present, and future. Oregon Rev Int Law 15:395-410

ASEAN (1976) Treaty of Amity and Cooperation in South East Asia. ASEAN, Bali Retrieved from http://asean.org/treaty-amity-cooperation-southeast-asiaindonesia-24-february-1976/

Berg, S. v. (2019). Reuters. Retrieved from Reuters: https://www.reuters.com/a rticle/us-myanmar-rohingya-world-court-idUSKBN1XL18S

Besheer, M. (2019). VOANEWS. Retrieved from VOA: https://www.voanews.com/a frica/gambia-sues-myanmar-genocide-against-rohingya-muslims\#: :text= The\%20Gambia\%2C\%20with\%20the\%20full,dealing\%20with\%20disputes\%2 Obetween\%20nations.

Crisp J (2018) 'Primitive people': the untold story of UNHCR's historical engagement with Rohingya refugees. Humanit Pract Net:13-18

Espenilla, Jacqueline Joyce F (2010) Injustice ignored: a case study of the irregular sea migration of the Rohingya Boat People. Asia Euro J 19(1):4-9

Holloway K, Fan L (2018) Dignity and the displaced Rohingya in Bangladesh: 'Ijjot is a huge thing in this world'. Humanitarian Policy Group (HPG), London

Human Rights Watch. (2019). Human rights watch. Retrieved from Human Rights Watch: https://www.hrw.org/news/2019/12/05/questions-and-answers-ga mbias-genocide-case-against-myanmar-international-court

IOM (2019) Glossary on migration. International Organization for Migration, Geneva

Jolliffe AS (2015) Forced migration: typology and local agency in Southeast Myanmar. Contemp Southeast Asia 37(2):211-241

Mehebub Sahana SJ (2019) Forced migration and the expatriation of the Rohingya: a demographic assessment of their historical exclusions and statelessness. J Muslim Minor Aff 39(1):45

Mohajan H (2018) History of Rakhine state and the origin of the Rohingya Muslims. Indone J Southeast Asian Stud 2:3-20 Retrieved from https://mpra. ub.uni-muenchen.de/88186/

Parnini SN (2013) The crisis of the Rohingya as a Muslim minority in Myanmar and bilateral relations with Bangladesh. J Muslim Minor Aff 33(2):281-289

Rahman KM (2015) Ethno-political conflict: the Rohingya vulnerability in Myanmar. Int J Humanit Soc Sci Stud 8(2):288-295

Smith M (2002) Burma (Myanmar): the time for change. Minority Rights Group International, UK

Smith M, Allsebrook A (1994) Ethnic groups in Burma. Anti-Slavery International, London

Tha MATB (2007) A short history of Rohingya and Kamans of Burma. Kaladan News, pp 5-10

The Republic of The Gambia Office of The President (2020). Retrieved from Statehouse: http://www.statehouse.gm/oic-tasks-gambia-lead-icj-caseagainstmyanmar

Ullah AA (2011) Rohingya refugees to Bangladesh: historical exclusions and contemporary marginalization. J Immigr Refug Stud 9(2):149-156

United Nation (1945) UN charter. United Nation, San Francisco

Worldometer. (2020). Retrieved from worldometer: https://www.worldometers. info/world-population/myanmar-population/\#: :text=Myanmar\%202020\%2 Opopulation\%20is\%20estimated,216\%20people\%20per\%20mi2).

\section{Publisher's Note}

Springer Nature remains neutral with regard to jurisdictional claims in published maps and institutional affiliations.

\section{Submit your manuscript to a SpringerOpen ${ }^{\circ}$ journal and benefit from:}

- Convenient online submission

- Rigorous peer review

- Open access: articles freely available online

- High visibility within the field

- Retaining the copyright to your article

Submit your next manuscript at $\boldsymbol{\nabla}$ springeropen.com 